\title{
Poor self-rated health and associated factors among elderly urban residents
}

\author{
Autoavaliação de saúde ruim e fatores associados \\ em idosos residentes em zona urbana \\ Autoevaluación de mala salud y factores \\ asociados en ancianos residentes en la zona urbana \\ Joana Darc Chaves Cardoso ${ }^{a}$ \\ Rosemeiry Capriata de Souza Azevedo \\ Annelita Almeida Oliveira Reiners ${ }^{c}$ \\ Cecília Victorazzo Louzada ${ }^{d}$ \\ Mariano Martinez Espinosa ${ }^{\mathrm{e}}$
}

DOl: $\quad$ http://dx.doi.org/10.1590/19831447.2014.04.46916

\footnotetext{
a Nurse. Master's degree. Faculty Member of the Departamento de Enfermagem da Universidade Federal de Mato Grosso- UFMT.

${ }^{b}$ Nurse. PhD. Faculty Member of the Departamento de Enfermagem da UFMT.

' Nurse. PhD. Faculty Member of the Departamento de Enfermagem da UFMT.

${ }^{d}$ Nurse. Master's degree. Faculty Member of the Faculdade de Enfermagem do Centro Universitário de Várzea Grande -UNIVAG.

e Statistician. PhD. Faculty Member of the Departamento de Estatística da UFMT.
}

\begin{abstract}
The purpose of this study was to examine the prevalence of bad self-rated health in the elderly and associated demographic and socioeconomic factors. This was an epidemiological, cross-sectional study. Data were collected through interviews using the BOAS (Brazil Old Age Schedule) questionnaire. The study included 573 elderly residents in the urban area of Cuiabá-MT, Brazil. The adopted measure of association was the prevalence ratio. For multivariate analysis, multiple Poisson regression was used. The prevalence of poor/very poor self-rated health was $30.9 \%$ and the associated factors were income, number of morbidities and urinary incontinence. The association of demographic and socioeconomic factors with poor/very poor self-rated health among the elderly in this study shows the need for assistance and policies that minimize the impact of these factors on the lives and health of the elderly.

Descriptors: Health status. Aged. Self-assessment.
\end{abstract}

\section{RESUMO}

Objetivou-se analisar a prevalência da autoavaliação de ruim/péssima e os fatores associados em idosos. Estudo epidemiológico, de corte transversal. Os dados foram coletados por meio de entrevista, utilizando o questionário BOAS (Brasil Old Age Schedule). Participaram do estudo 573 idosos residentes na zona urbana do município de Cuiabá-MT. A medida de associação utilizada foi a razão de prevalência. Na análise multivariada, utilizou-se a regressão múltipla de Poisson. A prevalência de autoavaliação de ruim/péssima foi de 30,9\%, e os fatores que se mantiveram associados foram renda, número de morbidades e incontinência urinária. A associação de fatores demográficos, socioeconômicos e de saúde à autoavaliação de saúde ruim/péssima dos idosos deste estudo mostra a necessidade de medidas assistenciais e políticas para minimizar o impacto desses fatores na vida e saúde dos idosos.

Descritores: Nível de saúde. Idoso. Autoavaliação.

\section{RESUMEN}

Este estudio tuvo como objetivo examinar la prevalencia de autoevaluación de los factores de pobre / muy pobre y asociados sobre los ancianos. Estudio epidemiológico, transversal. Los datos fueron recolectados a través de entrevistas utilizando el buen cuestionario BOAS (Brazil Old Age Schedule). El estudio incluyó a 573 ancianos residentes en la zona urbana de Cuiabá-MT. La medida de asociación utilizada fue la razón de prevalencia. En el análisis multivariante, se utilizó la regresión múltiple de Poisson. La prevalencia de la autoevaluación de la mala / muy mala fue del 30,9\% y los factores que se mantuvieron asociados eran ingresos, número de comorbilidades y la incontinencia urinaria. La asociación de los factores socioeconómicos, demográficos, y la autoevaluación de la salud de los pobres / muy mal estado de salud de los adultos mayores en este estudio muestra la necesidad de atención y las políticas para minimizar el impacto de estos factores sobre la vida y la salud de las medidas de mayor edad. Descriptores: Estado de salud. Anciano. Autoevaluación. 


\section{DINTRODUCTION}

Self-rated health has been used as a reliable method to measure and monitor the health status of individuals, and is a practical, low-cost method for healthcare services. It is an indicator of quality of life, morbidity and functional decline, and, above all, a solid predictor of morbidity, which is essential to evaluate the health conditions of elderly people ${ }^{(1)}$. This general self-classification of health status encompasses several aspects of the individual's life, such as physical, functional, cognitive and emotional factors, and well-being ${ }^{(2)}$.

There is a growing number of studies and research on self-rated health among the elderly ${ }^{(3-4)}$. Information on self-rated health among older people provides evidence on their health status and the impact it has on their lives.

Studies that focus on poor self-rated health among the elderly, however, are still scarse ${ }^{(5-6)}$. Existing studies on this topic show that poor self-rated health is associated to several factors, such as sedentarism, low weight and obesity, extensive use of medication and functional incapacity. Moreover, the risk of mortality associated to poor self-rated health is greater than in other objective health status assessments, such as physician-rated health ${ }^{(1)}$.

In this study, the concept of elderly was adopted from the World Health Organization (WHO), that establishes that an elderly person is 60 years or older. The object of this study was to analyse the prevalence of poor/very poor self-rated health among the elderly urban population considering associated demographic, socioeconomic and health-related factors.

\section{METHOD}

Research for this study was based on a master's dissertation titled, "Condições de saúde autorreferidas da população idosa do município de Cuiabá-MT" (Self-rated health conditions among the elderly population of the municipality of (uiaba-MT) $)^{(7)}$. Epidemiological cross-sectional research was conducted by means of home interviews in the municipality of Cuiabá-MT, Brazil. Elderly people who lived in long-stay institutions (LSI), hospitals, prisons, convents, lodging houses and support houses were excluded from the study. Other exclusions were elderly people with cognitive problems or any condition that prevented them from answering the questions, and those who resided in rural areas.

Sample group size was determined using the formula for the finite population. The probability-type sample was based on a stratification selection technique by cen- sus sector, reconsidering a confidence interval of 95\%, a sample error of 5\% and an estimated proportion of 50\% for the proportions of interest. This cluster sampling was used to determine the number of census sectors that would be visited, totalling 11 sectors. Considering a usual pattern effect of 1.5 to reach the desired research precision, the total corrected sample was 573 elderly individuals. To determine the number of elderly persons that would be interviewed in the urban districts of Cuiabá, the total number of elderly people living in each district stratified by sex was considered.

Data were collected at the homes of the elderly residents from December 2011 to March 2012, by trained interviewees using a BOAS (Brazil Old Age Schedule) questionnaire. This multi-dimensional tool has been used in several studies to explore various aspects related to the lives and health of the elderly population.

The variables analysed in this study and their respective categories were: Dependent variable - self-rated health, obtained from the question: In general, would you say that your health is excellent, good, poor or very poor? Independent variables - demographic characteristics: sex (male; female), age (60 to 69 years; 70 to 79 years; 80 years or older), martial status (married/stable union; widowed; single/separated/divorced). Socioeconomic characteristics (illiterate; up to 4 years of schooling; more than 4 years of schooling), monthly income (less than 2 minimum wages; 2 to 3 minimum wages; more than 3 minimum wages). Health conditions: number of self-referred morbidities ( 0 to 1 morbidity; 2 to 3 morbidities; 4 or more morbidities), use of medication (yes; no) and urinary inconsistence (UI) (yes; no).

Interview data were processed using SPSS 15.0 (Statistical Package for Social Sciences). Associations between dependent and independent variables underwent bivariate analysis by means of the chi-squared test and the prevalence ratio (gross prevalence ratio (PR) with the respective confidence intervals 95\% (Cl 95\%). Subsequently, the Poisson regression model was used to conduct a multivariate assessment of associations between the variable response or outcome and independent variables to obtain the adjusted prevalence. This model included all independent variables or factors that presented $p<0.20$ in bivariate analysis. The backward model was used to enter variables in the model. For these analyses, responses of the self-rated health variable, which at first had four questionnaire categories (excellent; good; poor; very poor) was transformed into a dichotomous variable (excellent/good and poor/ very poor).

This study was approved by the Research Ethics Committee of the Hospital Universitário Júlio Müller with proto- 
col number 132/2011. All participants signed an informed consent statement.

\section{RESULTS}

Of the 573 elderly persons, 254 were men and 319 were women. Average age was 71.6 years $(\mathrm{DP}=8.38)$, with predominance of the 60 to 69 age group (45.9\%). In relation to marital status, $72.8 \%$ of the men were married or in a stable union and $43.6 \%$ of the women were widowed. In terms of education, $26.5 \%$ did not know how to read or write and $44.4 \%$ had finished primary school. Most of the elderly interviewees (73.1\%) stated they had an income of less than two minimum wages.

Almost $70 \%$ of elderly participants evaluated their health status as excellent or good (69.1\%). Of these, most were women (53.6\%) were in the 60 to 69 age group
(46.6\%); were married or had companions (54.6\%); knew how to read and write (78.7\%), being that $45.5 \%$ had up to four years of schooling; and $67 \%$ claimed an income of under two minimum wages.

Of the elderly people who self-rated their health as poor or very poor (30.9\%), most were women (60.8\%); in the 60 to 69 age group (45.4\%); married or with a companion (52.8\%); knew how to read and write (61.4\%), being that $45.5 \%$ had up to four years of schooling; and $86.4 \%$ mentioned an income of under two minimum wages.

The prevalence ratio of poor/very poor self-rated health among the elderly with up to four years of schooling was 0.56 times higher in comparison to the elderly with more than four years of schooling, with a risk that was 1.30 times greater for those who were illiterate.

In relation to income, elderly participants with two to three minimum wages had a 2.63 greater risk of self-rating

Table 1. Bivariate analysis of the association between poor/very poor self-rated health status among the elderly, according to demographic and socioeconomic factors, Cuiabá-MT, Brazil, 2012.

\begin{tabular}{|c|c|c|c|c|c|c|c|}
\hline \multirow{3}{*}{ Variables } & \multicolumn{4}{|c|}{ Self-rated health status } & \multirow{3}{*}{$\mathbf{P R}_{\mathrm{g}}$} & \multirow{3}{*}{$\mathrm{Cl} 95 \%$} & \multirow{3}{*}{ p Value } \\
\hline & \multicolumn{2}{|c|}{ Poor/Very Poor } & \multicolumn{2}{|c|}{ Excellent/Good } & & & \\
\hline & $\mathbf{n}$ & $\%$ & $\mathbf{n}$ & $\%$ & & & \\
\hline \multicolumn{8}{|l|}{ Sex } \\
\hline Male & 69 & 27.38 & 183 & 72.62 & 1.00 & & \\
\hline Female & 107 & 33.65 & 211 & 66.35 & 1.23 & {$[0.95 ; 1.58]$} & 0.108 \\
\hline \multicolumn{8}{|l|}{ Age group } \\
\hline $60-69$ years & 79 & 30.15 & 183 & 69.85 & 1.00 & & \\
\hline $70-79$ years & 68 & 33.66 & 134 & 66.34 & 1.12 & {$[0.86 ; 1.46]$} & 0.420 \\
\hline 80 years or older & 27 & 26.21 & 76 & 73.79 & 0.87 & {$[0.60 ; 1.26]$} & 0.456 \\
\hline \multicolumn{8}{|l|}{ Schooling } \\
\hline More than 4 years & 31 & 19.50 & 128 & 80.50 & 1.00 & & \\
\hline 4 years or less & 77 & 30.31 & 177 & 69.69 & 1.56 & {$[1.08 ; 2.24]$} & $0.015 *$ \\
\hline Illiterate & 68 & 44.74 & 84 & 55.26 & 2.30 & {$[1.60 ; 3.30]$} & $<0.001 *$ \\
\hline \multicolumn{8}{|l|}{ Martial status } \\
\hline Married/Stable union & 93 & 30.19 & 215 & 69.81 & 1.00 & & \\
\hline Widowed & 57 & 32.57 & 118 & 67.43 & 1.08 & {$[0.82 ; 1.42]$} & 0.587 \\
\hline Single/Separated/ Divorced & 26 & 29.89 & 61 & 70.11 & 0.99 & {$[0.69 ; 1.42]$} & 0.956 \\
\hline \multicolumn{8}{|l|}{ Income } \\
\hline More than $3 \mathrm{MW}$ & 5 & 8.77 & 52 & 91.23 & 1.00 & & \\
\hline 2 to $3 \mathrm{MW}$ & 135 & 31.84 & 289 & 68.16 & 3.63 & {$[1.55 ; 8.48]$} & $<0.001 *$ \\
\hline Less than $2 \mathrm{MW}$ & 23 & 44.23 & 29 & 55.77 & 5.04 & {$[2.07 ; 12.29]$} & $<0.001 *$ \\
\hline
\end{tabular}


their health status as poor/very poor than those with more than three minimum wages. The elderly participants who earned less than two minimum wages had a 4.04 greater risk when compared to the elderly who received more than three minimum wages (Table 1).

In relation to health variables, the use of medication and $\mathrm{UI}$ also proved to be associated with poor/very poor self-rated health, being that the former presented a prevalence ratio of under one ( $\mathrm{Cl} 95 \%=0.18-0.53)$, indicating that this is a protection factor. That is, the use of medication reduced the risk of an elderly person self-rating health as poor/very poor. Contrarily, UI is a risk factor for poor/very poor self-rated health in the elderly (Cl 95\% $=1.50-2.41)$ (Table 2).

During multivariate analysis, the variables income, self-reported morbidity and UI remained associated with poor/very poor self-rated health in PR adjusted by robust Poisson regression, selected using the backward method (Table 3).

Evidence showed that the elderly participants with an income of two to three minimum wages presented a 1.34 greater risk of presenting poor/very poor self-rated health in comparison to those with more than three minimum wages. Of the elderly with less than two minimum wages, this risk was 1.68 times greater (Table 3 ).

The elderly with four or more self-reported morbidities presented poor/very poor self-rated health 3.28 times more frequently than those who reported they did not have morbidities or only suffered from one disease (Table 3 ).

Finally, it was observed that elderly participants with UI presented 0.33 times more risk of self-rating their health as poor/very poor, when compared to those who did not have UI (Table 3).

\section{DISCUSSION}

The prevalence of poor/very poor self-rated health in this study was $30.9 \%$, which is higher to the value found in the general population that included people that were 20 years old or older $(5.6 \%)^{(7)}$. This is probably due to the fact that this research was only conducted with people over the age of 60 . Academics show that poor self-rated health gets worse with age ${ }^{(8)}$. When compared to younger adults, elderly people tend to have poorer health, difficulty in accessing healthcare services, and a lower level of formal education and income ${ }^{(3,6)}$.

However, when the prevalence found in this study is compared to others on elderly populations, the frequency of poor self-rated health was similar in some studies $\left(27.7 \% \%^{(3)}\right.$ and $\left.27.5 \%{ }^{(5)}\right)$ and different in others $\left(17.1 \%{ }^{(6)}\right.$ and $\left.49.6 \%{ }^{(9)}\right)$. One of the reasons for these differences can be the health context of these elderly individuals. Variables such as structure of the healthcare system and access and use of health services has been associated to poorer

Table 2. Bivariate analysis of the association between poor self-rated health status based on health variables, Cuiabá-MT, Brazil, 2012.

\begin{tabular}{|c|c|c|c|c|c|c|c|}
\hline \multirow{3}{*}{ Variables } & \multicolumn{4}{|c|}{ Self-rated health } & \multirow{3}{*}{$\mathrm{PR}_{\mathrm{g}}$} & \multirow{3}{*}{$\mathrm{Cl} 95 \%$} & \multirow{3}{*}{ p Value } \\
\hline & \multicolumn{2}{|c|}{ Poor/Very poor } & \multicolumn{2}{|c|}{ Excellent/Good } & & & \\
\hline & $\mathbf{n}$ & $\%$ & $\mathbf{n}$ & $\%$ & & & \\
\hline \multicolumn{8}{|l|}{ Self-reported morbidity } \\
\hline 0 to 1 & 40 & 14.65 & 233 & 85.35 & 1.00 & & \\
\hline 2 to 3 & 116 & 43.61 & 150 & 56.39 & 2.98 & {$[2.17 ; 4.09]$} & $<0.001 *$ \\
\hline 4 or more & 19 & 65.52 & 10 & 34.83 & 4.47 & {$[3.03 ; 6.60]$} & $<0.001 *$ \\
\hline \multicolumn{8}{|l|}{ Use of medication } \\
\hline No & 12 & 10.91 & 98 & 89.09 & 1.00 & & \\
\hline Yes & 164 & 35.65 & 296 & 64.35 & 0.31 & {$[0.18 ; 0.53]$} & $<0.001 *$ \\
\hline \multicolumn{8}{|l|}{ Urinary inconsistency } \\
\hline No & 116 & 25.89 & 332 & 74.11 & 1.00 & & \\
\hline Yes & 60 & 49.18 & 62 & 50.82 & 1.90 & {$[1.50 ; 2.41]$} & $<0.001 *$ \\
\hline
\end{tabular}

Source: Research data.

PR : Gross prevalence ratio; Cl: 95\%; $\mathbf{p : ~ L e v e l ~ o f ~ s i g n i f i c a n c e ~ c o n s i d e r i n g ~ c h i - s q u a r e d ~ d i s t r i b u t i o n . ~}$ 
Table 3. Prevalence distribution of poor/very poor self-rated health in the elderly. Cuiabá-MT, Brazil, 2012.

\begin{tabular}{|c|c|c|c|}
\hline Variables & $\mathbf{P R}_{\mathrm{a}}$ & $\mathrm{Cl} 95 \%$ & $p$ Value \\
\hline \multicolumn{4}{|l|}{ Income } \\
\hline More than 3 MW & 1.00 & & \\
\hline 2 to $3 \mathrm{MW}$ & 2.34 & 1.08 to 5.02 & 0.030 \\
\hline Less than 2 MW & 2.68 & 1.19 to 6.07 & 0.018 \\
\hline \multicolumn{4}{|c|}{ Self-reported morbidity } \\
\hline 0 to 1 & 1.00 & & \\
\hline 2 to 3 & 2.94 & 2.10 to 4.11 & $<0.001 *$ \\
\hline 4 or more & 4.28 & 2.87 to 6.39 & $<0.001^{*}$ \\
\hline \multicolumn{4}{|c|}{ Urinary inconsistency } \\
\hline No & 1.00 & & \\
\hline Yes & 1.33 & 1.04 to 1.70 & 0.023 \\
\hline
\end{tabular}

Source: Research data.

PR : Prevalence ratio adjusted to the Poisson regression model with selection of variables; CI: $95 \%$; Level of significance: $5 \%$.

self-rated health ${ }^{(10)}$. Furthermore, socioeconomic factors, such as income and schooling, can reflect social inequalities in Brazil and their repercussions on the health of the population ${ }^{(11)}$.

Another finding of this investigation was a strong association of poor/very poor self-rated health with years of schooling, that is, with the elderly participants that had less years of schooling there was a progressive increase of PR in those who rated their health as being poor/very poor. This has been frequently confirmed in literature ${ }^{(4)}$. Studies show that elderly people who are illiterate or have lower education levels are more likely to evaluate their health as poor in comparison to those with more years of schooling ${ }^{(5,8)}$. Recent research shows that the frequency of people who self-rated their health as poor/very poor was higher among people with lower education levels (22.3\%) ${ }^{(8)}$.

This probably occurs because in Brazil today's elderly population had less access to education in comparison to the younger population ${ }^{(12)}$. Consequently, improvements in the educational levels of people may favour the adoption of a healthier lifestyle and encourage the search of healthcare services and access to information ${ }^{(4)}$.

Another observed association is related to the use of medication and poor/very poor self-rated health. Studies have found associations of the use of medication with poor self-rated health ${ }^{(5)}$. In other words, those who rate their health negatively consume a greater number of pharmaceutical drugs ${ }^{(9)}$.

In this study, this variable appeared as a protection factor. This could be because when older people perceive themselves as sick, they seek health services to solve their problems, which are minimized or controlled by prescribing medication. For this purpose, the Política Nacional de Assistência Farmacêutica (National Pharmaceutical Assistance Policy) ensures the availability of resources to acquire medication, organize services and train professionals. Moreover, it facilitates access and rational use of medication and effective insertion of pharmaceutical assistance in the scope of the SUS, or Unified Health Service ${ }^{(13)}$. It is believed that access to health services and the prescription and use of medication may lead the elderly to better selfrate their health.

There is a consensus in literature that the use of medication is essential for the well-being of the elderly, especially of those with chronic diseases or ailments. However, authors emphasize that despite their beneficial effect, they can be harmful when used incorrectly, when treatment is not followed adequately, or as a result of their adverse effects and drug interactions. This can lead to negative repercussions on the health status and quality of life of the elderly and may increase the rate of morbidities and death ${ }^{(9)}$.

One of the findings of this work was a stronger association between poor/very poor self-rated health and income than with schooling $(p=0.001)$. A similar result was found in a North American study, in which income was a more robust predictor of self-rated health than education $^{(10)}$. In fact, academics have proved that income is one of the main determining factors of people's health status, especially of the elderly. When income is low, it interferes negatively on how individuals perceive and care for their 
own health, on their access and use of health services and on their adherence to treatment ${ }^{(14)}$. Another hypothesis for this finding is the large number of elderly people who live with their families. This can result in a better income and access to health services, which favourably influences the way they rate their health.

A positive association between poor/very poor self-rated health and the number of chronic diseases was also found in this study and corroborated by other authors ${ }^{(15)}$. A study conducted in Brazilian capital cities and the Federal District showed that the PR of poor health in the presence of four or five morbidities was 6.9 for women and 11.4 for men in comparison to those who did not have morbidities ${ }^{(15)}$.

These findings indicate the negative influence of the number of chronic diseases in self-rated health. It is notorious that chronic disease, especially among the elderly, impairs functional capacity and the performance of everyday activities ${ }^{(16)}$. This impairment can bring implications to the elderly, their families, their community and health services by directly interfering in the quality of life and well-being of this population ${ }^{(17)}$.

Policies that address the promotion of health and the prevention and treatment of chronic diseases have proven more effective to control their implications, consequently increasing life span and quality of life ${ }^{(18)}$.

The strong association of $\mathrm{UI}$ with poor/very poor self-rated health was another factor revealed in this study and corroborated by findings of other authors ${ }^{(19)}$. A study with data of the Saúde, Bem Estar e Envelhecimento (SABE) project conducted in the municipality of São Paulo on an elderly population showed that for people aged 75 or more who self-rated their health as good, the prevalence of UI was $22.5 \%$, while among those who stated that their health was regular or poor, this percentage almost doubled, reaching $41.5 \%{ }^{(19)}$. These data showed that this condition significantly influences the way the elderly evaluate their own health.

In fact, $\mathrm{UI}$ is a prevalent condition among the elderly, more so among women than men, and among those with chronic diseases ${ }^{(20)}$. This condition causes embarrassing and stressful situations that negatively impact their self-esteem and quality of life, oftentimes resulting in social isolation ${ }^{(19)}$.

\section{- CONCLUSION}

This is one of the few studies conducted in Brazil that sought to analyze poor self-rated health in elderly urban residents. Furthermore, the sample is considerable and representative of the urban population in the municipality, allowing generalizations.
The results of this study provide further knowledge on issues related to the lives and health of the elderly population in Brazil. It can also help managers plan activities that focus on promoting health and preventing the aggravations and incapacities that affect this population. Moreover, it can encourage healthcare professionals, especially in the field of nursing, to incorporate self-rated health in routine practices and the global evaluations of elderly users to identify their vulnerabilities.

It was concluded that the prevalence of poor/very poor self-rated health was $30.9 \%$ and that associated factors were income, number of morbidities and UI. The use of medication as a protection factor was a unique finding, considering that in other studies it is singled out as a risk factor.

The association of these factors to poor/very poor self-rated health among the elderly of this study shows the need for care measures and policies that minimize their impact on the lives and health of this population.

This study did have some limitations. Firstly, the sample was restricted to elderly urban residents and does not reflect the reality of the entire population of people aged 60 or over in the municipality. Therefore, considering that the locations in which people reside determine aspects of their lives and health, studies that show these specificities are important.

Secondly, research did not include institutionalized elderly patients. This segment is more vulnerable given their health condition, which could interfere with the results found in this study. Consequently, investigations on poor self-rated health among the institutionalized elderly would provide important additional information to better assist and understand this population.

\section{REFERENCES}

1. Giltay EJ, Vollaard AM, Kromhout D. Self-rated health and physician-rated health as independent predictors of mortality in elderly men. Age Ageing. 2012;41:165-71. doi: 10.1093/ageing/afr161.

2. Simon JG, De Boer JB, Joung IMA, Bosma H. Perceived Health. How is your health in general? A qualitative study on self-assessed health. Eur J Public Health. 2012;15(2):200-8. doi:10.1093/eurpub/cki102.

3. Hu YN, Hu GC, Hsu CY, Hsieh SF, Li CC. Assessment of individual activities of daily living and its association with self-rated health in elderly people of Taiwan. International J Gerontol. 2012;6:117-21. doi:10.1016/j.jige.2012.01.024.

4. Borim FSA, Barros MBA, Neri AL. Autoavaliação da saúde em idosos: pesquisa de base populacional no Município de Campinas, São Paulo, Brasil. Cad Saúde Pública [Internet]. 2012 [accessed Jan 12, 2013];28(4):769-80. Available at: http://www.scielo.br/pdf/csp/v28n4/16.pdf.

5. Pagotto V, Nakatani AYK, Silveira EA. Fatores associados à autoavaliação de saúde ruim em idosos usuários do Sistema Único de Saúde. Cad Saúde Pública 
[Internet]. Rio de Janeiro. 2011 [accessed Sept 23, 2012];27(8):1593-602. Available at: http://www.scielosp.org/pdf/csp/v27n8/14.pdf.

6. Nunes APN, Barreto SM, Gonçalves LG. Relações sociais e autopercepção da saúde: projeto envelhecimento e saúde. Rev Bras Epidemiol [Internet]. 2012 [Accessed Jan 12, 2013];15(2):415-28. Available at: http://www.scielo.br/pdf/ rbepid/v15n2/19.pdf.

7. Cardoso JDC. Condições de saúde autorreferidas da população idosa do município de Cuiabá-MT [dissertation]. Cuiabá: Universidade Federal de Mato Grosso; 2013.

8. Moraes JR, Moreira JPL, Luiz RR. Associação entre o estado de saúde autorreferido de adultos e a área de localização do domicílio: uma análise de regressão logística ordinal usando a PNAD 2008. Ciênc. Saúde Colet [Internet]. 2011[Accessed Sept 12, 2012];16(9):3769-80. Available at: http://www.scielo.br/pdf/ csc/v16n9/a13v16n9.pdf.

9. Silva RJS, Smith-Menezes A, Tribess S, Rómo-Perez V, Virtuoso Júnior JS. Prevalência e fatores associados à percepção negativa da saúde em pessoas idosas no Brasil. Rev Bras Epidemiol [Internet]. 2012 [Accessed Jan 20, 2013];15(1):4962. Available at: http://www.scielosp.org/pdf/rbepid/v15n1/05.pdf.

10. Louvison MCP, Lebrão ML, Duarte YAO, Santos JLF, Malik AM, Almeida ES. Desigualdades no uso e acesso aos serviços de saúde entre idosos do município de São Paulo. Rev Saúde Pública [Internet]. 2008 [Accessed June 12, 2012];42(4):733-40. Available at: http://www.scielo.br/pdf/rsp/v42n4/6846.pdf.

11. Dachs JNW, Santos APRS. Auto-avaliação do estado de saúde no Brasil: análise dos dados da PNAD/2003. Ciênc Saúde Colet [Internet]. 2006 [Accessed June 12, 2012];11(4):887-894. Available at: http://www.scielo.br/pdf/csc/ v11n4/32327.pdf.

12. Barros MBA, Francisco PMSB, Lima MG, César CLG. Social inequalities in health among the elderly. Cad Saúde Pública [Internet]. 2011 [Accessed June 12, 2012];27 Supl 2:S198-S208. Available at: http://www.scielo.br/pdf/csp/ v27s2/08.pdf.

\section{Author's address:}

Joana Darc Chaves Cardoso

Faculdade de Enfermagem da UFMT

Avenida Fernando Correa da Costa, 2367, Boa Esperança

78060-900, Cuiabá, MT

E-mail: joana-qtal@hotmail.com
13. Conselho Nacional de Secretários de Saúde (BR). Assistência farmacêutica no SUS. Brasília: CONASS, 2007.

14. Lima-Costa MF, Facchini LA, Matos DL, Macinko J. Mudanças em dez anos das desigualdades sociais em saúde dos idosos brasileiros (1998-2008). Rev Saúde Pública [Internet]. 2012 [Accessed Feb 23, 2013];46(Supl 1):100-7. Available at: http://www.scielosp.org/pdf/rsp/v46s1/a04207.pdf.

15. Barros MBA, Zanchetta LM, Moura EC, Malta DC. Auto-avaliação da saúde e fatores associados, Brasil, 2006. Rev Saúde Pública [Internet]. 2009 [Accessed Jan 12, 2012];43(Supl 2):27-37. Available at: http://www.scielo.br/pdf/rsp/v43s2/ a0792.pdf.

16. Nunes DP, Nakatani AYK, Silveira EA, Bachion MM, Souza MR. Capacidade funcional, condições socioeconômicas e de saúde de idosos atendidos por equipes de saúde da família de Goiânia (GO, Brasil). Ciênc Saúde Colet [Internet]. 2010 [Accessed June 12, 2012];15(6):2887-98. Available at: http://www.scielo.br/ $\mathrm{pdf} / \mathrm{csc} / \mathrm{v} 15 \mathrm{n6} / \mathrm{a} 26 \mathrm{v} 15 \mathrm{n6} . \mathrm{pdf}$.

17. Alves $L C$, Leimann BCQ, Vasconcelos MEL, Carvalho MS, Vasconcelos AGG, Fonseca TCO, et al. A influência das doenças crônicas na capacidade funcional dos idosos do Município de São Paulo, Brasil. Cad Saúde Pública [Internet]. 2007 [Accessed June 12, 2012];23(8):1924-30. Available at: http://www.scielo.br/ $\mathrm{pdf} / \mathrm{csp} / \mathrm{v} 23 \mathrm{n} 8 / 19 . \mathrm{pdf}$.

18. World Health Organization. Envelhecimento ativo: uma política de saúde. Suzana Gontijo (tradutor). Brasília: Organização Pan-Americana da Saúde, 2005.

19. Tamanini JTN, Lebrão ML, Duarte Y, Santos JLF, Laurenti R. Analysis of the prevalence of and factors associated with urinary incontinence among elderly people in the municipality of São Paulo, Brazil: SABE study (health, wellbeing and aging). Cad. Saúde Pública [Internet]. 2009 [Accessed June12, 2012];25(8):1756-62. Available at: http://www.scielosp.org/pdf/csp/v25n8/11.pdf.

20. Burti JS, Santos AMB, Pereira RMR, Zambon JP, Marques AP. Prevalence and clinical characteristics of urinary incontinence in elderly individuals of a low income. Arch Gerontol Geriatr. 2012;54(2):e42-e46.

Received: 11.05.2014

Approved: 24.11.2014 